\title{
Sample Preparation for Atomic Spectroscopy: Evolution and Future Trends
}

\author{
Elisabeth de Oliveira
}

Instituto de Química, Universidade de São Paulo, Av. Prof. Lineu Prestes, 748, 05508-9000 São Paulo - SP, Brazil

\begin{abstract}
A preparação da amostra é a etapa crítica dentro de um protocolo analítico e envolve desde a simples diluição até a solubilização parcial ou total. Métodos de decomposição por via seca ou úmida, envolvendo o aquecimento das amostras em sistemas abertos ou fechados, utilizando várias formas de energia como térmica, ultra-som ou radiante (infravermelho, ultravioleta e microondas) são empregados. O presente e o futuro da preparação de amostras consideram também solubilização em linha de amostras, lixiviação dos analitos de interesse, especiação, análise de suspensão, análise in situ, in vivo etc. Ênfase foi dada para o preparo de amostras para espectroscopia atômica. Atualmente, os objetivos a serem alcançados envolvem a obtenção do melhor resultado, no menor tempo, com mínima contaminação, pouco gasto de reagente e pequena geração de resíduos e efluentes, bem como a integridade das amostras e traceabilidade dos resultados, tendo em mente a qualidade e confiança nos resultados de medições, como requerido pela comunidade e usuários.
\end{abstract}

Sample preparation is the critical step of any analytical protocol, and involves steps from simple dilution to partial or total dissolution. The methods include dry or wet decomposition of the samples in open or closed systems, using thermal, ultrasonic or radiant (infrared, ultraviolet and microwaves) energy. This review emphasizes sample preparation for atomic spectroscopy. The present and future tendencies for sample preparation also involve on-line dissolution, extraction of the analytes, speciation, solid sample and slurry analysis, in situ and in vivo procedures, etc. Nowadays the goals are the best result, in the shortest time, with minimum contamination, using the smallest quantities of reagents and samples, and having low residue and waste generation, as well as maintaining the integrity of the sample and the traceability of the results, to have quality and confidence in the measurements as the primordial attributes required by the community and by the users.

Keywords: sample preparation, wet and dry digestion, radiant energy, thermal energy, ultrasonic energy, microwaves

\section{Introduction}

Elemental analysis of the majority of organic and inorganic matrices requires the partial or total dissolution of the sample prior to instrumental analysis. Only a few direct methods allow the introduction of the sample without any preparation, as presented in Table $1 .{ }^{1}$ In these cases the lack of reliable calibration is the major problem. On the other hand, sample preparation allows the separation and/or pre-concentration of analytes and makes possible the use of several determination methods (Table 1).

Sample preparations involve digestion, extraction and preparation of the analytes before the analysis, ${ }^{2-8}$ so this step is time limiting, requiring $c a .61 \%$ of the total time to perform the complete analysis, and is responsible for $30 \%$ of the total analysis error. ${ }^{7}$ Nowadays the goals to be reached

\footnotetext{
* e-mail: edolivei@iq.usp.br
}

Table 1. Relationship between sample preparation and determination methods

\begin{tabular}{ll}
\hline Methods that allow direct sample analysis & $\begin{array}{l}\text { X-ray Fluorescence } \\
\text { Neutron Activation } \\
\text { Thermogravimetry } \\
\end{array}$ \\
Spectrographic \\
\hline Methods that need sample preparation & Gravimetry \\
(separation and pre-concentration) & Titrimetry \\
& Spectrometry \\
& Electro-analysis \\
& Chromatography \\
\hline
\end{tabular}

are the best results, in the shortest time, with minimal contamination, low reagent consumption and generation of minimal residue or waste.

In order to achieve the real objectives of the analysis, some aspects of sample preparation should be taken into account, focusing on the chosen procedure. Thus, 
simplification in sample manipulation, use of high purity water and reagents in suitable amounts, correct cleaning of recipients and blank preparation in parallel to the samples are desirable. Also the validation of the methodology is important, usually with certified reference materials. ${ }^{2,6-8}$

This review presents several available methods for sample preparation, with emphases on application in atomic spectroscopy, and describes future trends in this area.

\section{Sample Preparation}

Sample preparation can be performed by simple dilution, or with heating for pre-concentration or partial or total dissolution. However to achieve most sample preparations, it is necessary to add reagents to the sample and to apply enough energy to break some bonds and the crystalline structure of solids. If necessary, it is possible to use complementary reagents to obtain the analytes in solution. Two basic procedures are normally used for sample preparation: dry and wet decomposition. .,6,, $910^{2}$

\subsection{Dry dissolution}

2.1.1. Fusion and dry ashing. Dry decomposition by fluxes (fusion processes) is normally used for silicates, refractory materials, some mineral oxides and iron alloys. The sample is mixed with a flux and then fused to form products that can be dissolved in water or dilute acid. The temperature required is high $\left(300\right.$ to $1000{ }^{\circ} \mathrm{C}$ ), and it is achieved by flame, conductive or microwave assisted heating. Some examples of fluxes are presented in Table $2 .{ }^{6}$ The disadvantages of this method are the impurities in the fluxes, the high content of electrolytes in the resulting solution, especially in the case of some analytical spectroscopic techniques, risk of contamination and losses by volatilization. ${ }^{2,6,7,10-16}$

Table 2. Fusion sample preparation

\begin{tabular}{ll}
\hline Temperature & $300-1000{ }^{\circ} \mathrm{C}$ \\
\hline Fluxes & Lithium metaborate \\
& Sodium carbonate \\
& Potassium nitrate \\
& Alkaline hydroxides \\
\hline Crucible & Platinum, nickel, silver, iron, \\
& graphite, porcelain \\
\hline Disadvantages & High content of dissolved solids \\
\hline
\end{tabular}

Dry ashing ${ }^{2,3,6,7,17}$ is used for the elimination or minimization of organic materials, prior to mineral element determination, and consists of the ignition of the organic compound in air or in a stream of oxygen. To avoid losses of volatile elements such as $\mathrm{As}, \mathrm{Cd}, \mathrm{Hg}$ and $\mathrm{Pb}$, additives can be used. Some examples are presented in Table 3.6.17

Table 3. Additives for dry ashing sample preparation

\begin{tabular}{ll}
\hline Temperature & $500-800{ }^{\circ} \mathrm{C}$ \\
\hline Additives to avoid losses of: & \\
Volatile elements (As, $\mathrm{Hg}, \mathrm{Pb})$ & Magnesium nitrate \\
Volatile chlorides ( $\mathrm{Zn}, \mathrm{Sn}$ etc.) & Sulfuric acid \\
and volatile elements & \\
\hline
\end{tabular}

\subsection{Wet dissolution}

For wet decomposition, oxidizing agents are used to decompose the organic samples prior to metal content determination or to extract metals from inorganic matrices, allowing their determination. Normally concentrated acid plus heating is used, and the important aspects to consider are the strength of the acid, its oxidizing and complexing power, its boiling point, the solubility of the resulting salts, safety in manipulation, and purity. ${ }^{2-8,18,19}$ For open vessel decomposition, the boiling point of the acid controls the maximum temperature to be used in order to avoid high acid consumption and possible losses of the volatile elements. ${ }^{2,67}$ Nitric acid, hydrochloric acid, sulfuric acid, phosphoric acid, hydrofluoric acid and hydrogen peroxide, as well as mixtures of such reagents, are used for organic samples, metallic alloys, common minerals, soils, rocks, clays and silicates.

Special care must be taken when hydrofluoric or perchloric acids are used. For hydrofluoric acid, PTFE or other plastic materials must be used and it must be emphasized that contact of HF with skin results in serious damage and should be avoided. Perchloric acid should never be more concentrated than $72 \%$, in the presence of organic matter due to the risk of explosion. Additional details can be found in references 6 and 7 .

Wet procedures can be performed using different forms of energy: thermal, ultrasonic and radiant (infrared, ultraviolet and microwave).

\subsubsection{Wet decomposition-thermal energy. Open vessel} decomposition can be performed using heat from a Bunsen

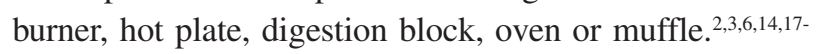
${ }^{19}$ The main problems to consider are: time consumption (hours), the use of large amounts of reagents, contamination from the environment, pre-concentration of reagent impurities, the use of strong oxidizing agents, such as hydrogen peroxide, and the need of constant 
supervision. The analyst also should be well prepared. For some refractory materials, such methods are not adequate. Even so, for many cases, reliable results can be achieved. ${ }^{3,6,8,10,17-19}$ Examples are presented in Table $4 .^{6}$

Table 4. Examples of wet dissolution- thermal energy for several ores

\begin{tabular}{lcc}
\hline Samples & Analytes & Reagents \\
\hline Silicates & Traces & $\mathrm{HF}+\mathrm{H}_{2} \mathrm{SO}_{4}$ \\
Chromium ore & Traces & $\mathrm{H}_{2} \mathrm{SO}_{4}+\mathrm{HCl}+\mathrm{NaCl}^{\mathrm{a}}$ \\
$\begin{array}{l}\text { Magnetite } \\
\text { Pyrite }\end{array}$ & $\mathrm{Ge}$ & $\mathrm{H}_{3} \mathrm{PO}_{4}+\mathrm{KMnO}_{4}$ \\
Magnesium ores & Traces & $\mathrm{HCl}+\mathrm{HNO}_{3}$ \\
Mraces & $\mathrm{HCl}$ \\
Monasite & $\mathrm{Ln}^{\mathrm{b}}$ & (digestion of the residue) \\
Fluorite & Traces & $\mathrm{H}_{2} \mathrm{SO}_{4}+\mathrm{H}_{2} \mathrm{O}_{2}$ \\
Mercury ores & Traces & $\mathrm{H}_{2} \mathrm{SO}_{4}+\mathrm{HCl}$ \\
Bauxite & $\mathrm{HCl}+\mathrm{HNO}_{3}+\mathrm{H}_{2} \mathrm{SO}_{4}{ }^{\mathrm{c}}$ \\
Sulfide ores & $\mathrm{Hraces}$ & $\mathrm{HCl}+\mathrm{HNO}_{3}+\mathrm{H}_{2} \mathrm{SO}_{4}$ \\
\hline
\end{tabular}

${ }^{a} \mathrm{NaCl}$ is used to form and remove volatile $\mathrm{CrOCl}_{2}$; ${ }^{\mathrm{b}} \mathrm{Ln}$ : lanthanide elements; Evaporation of the $\mathrm{HgCl}_{2}$.

Wet decomposition performed in a pressure decomposition container, in order to avoid contamination and loss of volatile elements, was first tested by Carius (1860), ${ }^{4,6,18}$ using a thick-walled glass tube, where the sample and reagents were combined and the tube was then sealed. It should be mentioned that during heating, explosions could occur. Samples are held at 250-300 ${ }^{\circ} \mathrm{C}$ for 3-6 h in most procedures. Tölg and coworkers ${ }^{20}$ and Bernas ${ }^{21}$ proposed the use of pressurized PTFE bombs, small masses of sample (200 to $500 \mathrm{mg}$ ) plus acid or a mixture of acids, and pointed out that increasing temperatures speed up the decomposition. Tölg's bombs are used especially in trace element analysis with organic, biological and inorganic samples, alloys, metals, and minerals. An adapted pressure decomposition Tölg's bomb is shown in Figure $1^{6,18,20}$ as employed nowadays. It is constituted of: pressure valve, screw-cap, pressure spring, metal lid, PTFE lid, PTFE insert and a pressure vessel (lined with stainless steel and thermal insulation). It rests in an aluminum heating block with a thermal probe, a cold water connection and a heating current connection with an over-heating fuse. During the decomposition in the PTFE vessel, the temperature limit is about $170{ }^{\circ} \mathrm{C}$ and the sample contain up to $100 \mathrm{mg}$ of carbon for the $35 \mathrm{~mL}$ vessel.

More recently, Knapp presented a high-pressure asher ${ }^{22}$ that makes possible to perform decompositions at 180 to $300{ }^{\circ} \mathrm{C}$, generating practically carbon-free solutions. By adding an external pressure of $10 \mathrm{MPa}$ for $300{ }^{\circ} \mathrm{C}$, the vapor and gas pressure, generated during the decomposition, are compensated. The autoclave with the heating element

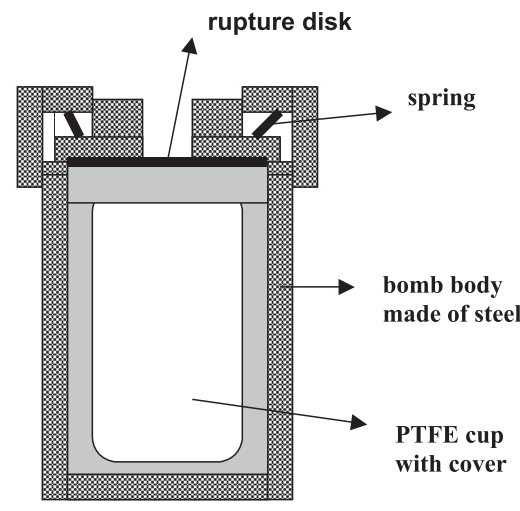

Figure 1. Scheme of Tölg's PTFE bomb for sample preparation.

contains an autoclave lid and lock ring. The heating block insert contains the quartz decomposition vessel with its own lid, and this vessel contains the sample to be decomposed, along with the acid (nitric acid as a rule). The quartz decomposition device is closed using a thin PTFE foil and a quartz lid (Figure 2). Analytes (chemical species) are present in inorganic forms in the decomposition solution. The amount of biological sample can contain up to $100 \mathrm{mg}$ $\mathrm{C}$ for a $30 \mathrm{~mL}$ vessel and up to $230 \mathrm{mg} \mathrm{C}$ for a $70 \mathrm{~mL}$ vessel when treated at $300{ }^{\circ} \mathrm{C}$ and up to $350 \mathrm{mg} \mathrm{C}$ for a $30 \mathrm{~mL}$ vessel and $800 \mathrm{mg} \mathrm{C}$ for a $70 \mathrm{~mL}$ vessel if treated at $180{ }^{\circ} \mathrm{C}$. Typical decomposition times using Tölg's bomb and highpressure asher vary from 1 to $3 \mathrm{~h}^{18}$

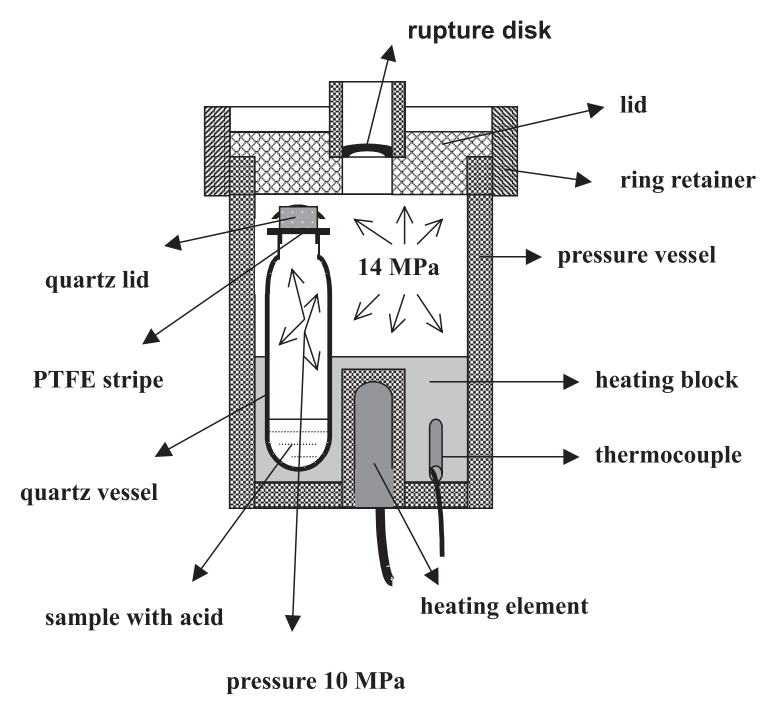

Figure 2. Scheme of Knapp's High Pressure Asher for sample preparation.

2.2.2. Wet decomposition/extraction-ultrasonic energy. A few years ago, ultrasound-assisted metal extraction was proposed as a simple and inexpensive alternative for sample 
preparation for biological and inorganic matrices. The extraction effect is considered as being caused by acoustic cavitation, that is, bubble formation and subsequent disruptive action. The collapse of bubbles, created by sonication of solutions, results in the generation of extremely high local temperature (ca. $5000 \mathrm{~K}$ ) and pressure (ca.10 GPa) gradients, which help sample preparation. ${ }^{18,23}$

A diluted acid medium is normally used, thus decreasing blank values and reducing both reagent and time consumption, as compared to traditional wet digestion using conductive or microwave-assisted heating. Also a smaller sample amount is used. ${ }^{18,23}$ This method, using a bath system, allows the preparation of several samples directly in the sample container, preventing sample losses and minimizing contamination, and is mainly used for extraction of the analytes. Ultrasound probes are generally employed for decomposition of organic compounds in environmental samples. Examples are presented in the literature for sample pretreatment $^{24-26}$ and also for synthesis. ${ }^{27}$

\subsubsection{Wet decomposition- radiant energy-infrared} radiation. Infrared-assisted element extraction has been employed for organic and biological samples. ${ }^{28-31}$ Infrared radiation $\left(1.2 \times 10^{-14}\right.$ to $\left.6.0 \times 10^{-12} \mathrm{~Hz}\right)$ causes an increase in molecular vibration and variation in molecular rotation, generating heat and also its propagation.

Usually, a small amount of biological sample, $c a .200$ $\mathrm{mg}$, plus $2 \mathrm{~mL}$ of nitric acid in a small glass flask (ca. 4 $\mathrm{mL}$ ) is placed in the focus of three IR lamps. After applying $10 \mathrm{~V}$ during 120 to $180 \mathrm{~s}, 1 \mathrm{~mL}$ of hydrogen peroxide is then added, followed by application of $10 \mathrm{~V}$ for $60 \mathrm{~s}$. Analytes are analyzed directly in the same tube, avoiding contamination of the solution. ${ }^{31}$ Other applications are, for example, the heating of liquid and solid samples for determination of volatile analytes,${ }^{28}$ and for the preparation of sub-boiling acids. ${ }^{32}$

\subsubsection{Wet Dissolution- radiant energy-ultraviolet} radiation. Ultraviolet radiation decomposition devices are used for complete removal of organic materials, normally when polarography or voltametry is used for subsequent elemental determination. ${ }^{18,33-35}$ Examples are heavy metal determination in waste-waters or liquid foodstuffs such as beer and wine. ${ }^{18}$ Ultraviolet radiation decomposition requires the addition of a small amount of acid plus hydrogen peroxide to the sample, without a significant increase in the temperature. This allows low contamination levels from reagents and avoids losses of volatile elements. Highly reactive chemical radicals are produced by UV radiation and ozone is generated which can be drawn away using a laboratory hood. In secondary reactions, organic substances, which bind to heavy metals, are degraded. Several quartz tubes containing sample and reagents can be arranged around a UV emitter placed in the center. ${ }^{18}$

Cavicchioli and Gutz described an in-line sample photo-digestion of organic matter in aqueous solution for voltammetric flow analysis of heavy metals in water samples. $^{33}$

\subsubsection{Wet decomposition- radiant energy-microwave} radiation. Microwave-assisted sample preparation is now used for a wide range of applications, including decomposition of inorganic and organic materials. ${ }^{4-9,18,19,34-37}$ The interaction of microwave radiation $(2450 \mathrm{MHz}, 12.2$ $\mathrm{cm}$ ) with sample and reagents causes both ionic migration and dipole rotation, resulting in fast heating of the mixture with consequent decomposition.

The advantages of this strategy are the short time needed (minutes) to perform decomposition of the sample, direct heating of samples and reagents (the vessels are only indirectly heated by the hot solution), minimal contamination and no loss of volatile elements. The use of small amounts of reagents decreases the blank signal.

Both a focused microwave oven (a wave-guided type microwave digestion system) and a conventional microwave oven (a cavity microwave digestion system) are presented in Figure 3. Both are available commercially. ${ }^{7,18,37}$

a)

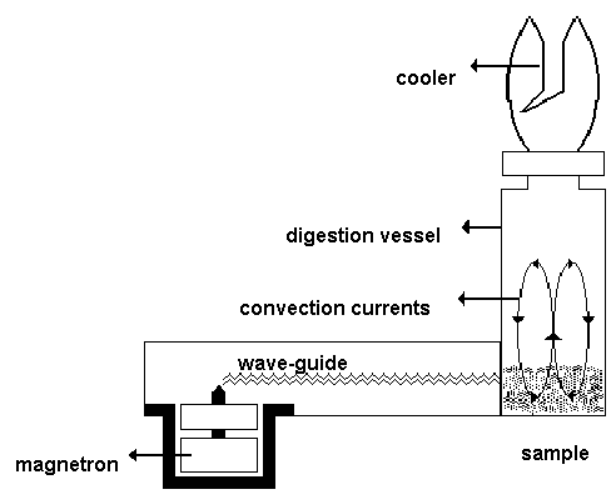

b)

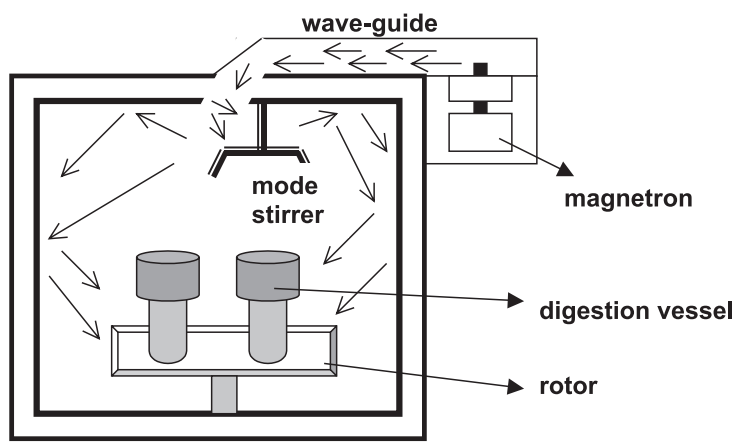

Figure 3. Microwave Digestion System: a) waveguide type and b) cavity type. 
The focused microwave oven operates at atmospheric pressure, can be used for sample masses up to $10 \mathrm{~g}$, and is adequate for samples with high concentrations of organic materials. It allows control of temperature $v s$. time or power $v s$. time (with simultaneous temperature measurement). The tubes are made of glass, quartz or PTFE, when hydrofluoric acid is used, and are transparent to microwave radiation. Temperature control should be programmed according to the boiling points of the acid or acid mixture used (Table 5). ${ }^{4}$

Table 5. Boiling points of concentrated acid solutions and aquaregia at atmospheric pressure

\begin{tabular}{lcc}
\hline Acid & Concentration $\%(\mathrm{~m} / \mathrm{v})$ & b.p. ${ }^{\circ} \mathrm{C}$ \\
\hline $\mathrm{HCl}$ & 37 & 110 \\
$\mathrm{HF}$ & 49 & 108 \\
$\mathrm{HNO}_{3}$ & 70 & 120 \\
$\mathrm{Aqua}$ regia & $\left(\mathrm{HCl}: \mathrm{HNO}_{3} 3: 1 \mathrm{v} / \mathrm{v}\right)$ & 112 \\
$\mathrm{H}_{2} \mathrm{SO}_{4}$ & 98.3 & 338 \\
$\mathrm{H}_{3} \mathrm{PO}_{4}$ & 85 & 150 \\
$\mathrm{HclO}_{4}$ & 72.4 & 203 \\
\hline
\end{tabular}

Usually, a mixture containing nitric acid plus hydrogen peroxide is used for botanic, biological and food (cereals, algae, pasta, etc.) samples. Sulfuric acid plus hydrogen peroxide is used for lubrication oils, PVC chips, polypropylene, polyamide, polyester and food (cornstarch, spinach, peanut butter etc.) samples. ${ }^{67,35-37}$ Acid mixtures (nitric plus hydrochloric acid etc.) are recommended for inorganic materials, such as some metals, alloys, minerals, and for metal extraction from soils and sediments. ${ }^{6,735-37}$

The conventional microwave oven operates at high pressures, which depend on the type of digestion flask, for the decomposition of samples using nitric and other mineral acids. Sealed PTFE vessels have pressures up to 7 $\mathrm{MPa}$ and quartz tubes up to $12 \mathrm{MPa}$ (especially when sulfuric acid is used). Vessels and microwave ovens present different security devices, depending on the manufacturer. The details have been described. ${ }^{6,728,37}$

The heating program can control pressure $v s$. time or temperature $v s$. time or power $v s$. time. It should be emphasized that the temperature to be used should be based on the boiling point of the acid or mixture used, as shown in Table $6 .{ }^{4}$ The relationship between pressure and sample amount is presented in Table 7.,7,35-37 Thus, applications include practically all inorganic and organic samples to be submitted to complete or partial decomposition, especially for refractory materials and for foods with high contents of carbohydrates, proteins and lipids. Examples are presented in the literature. ${ }^{4-7,28,35-37}$

The advantages of using microwave ovens are the security of the commercially available equipment, the short
Table 6. Boiling point of concentrated acid solutions and aqua-regia at $7 \times 10^{5} \mathrm{~Pa}$ of pressure in a sealed vessel

\begin{tabular}{lcc}
\hline Acid & Concentration $\%(\mathrm{~m} / \mathrm{v})$ & b.p. ${ }^{\circ} \mathrm{C}$ \\
\hline $\mathrm{HCl}$ & 37 & 140 \\
$\mathrm{HF}$ & 49 & 175 \\
$\mathrm{HNO}_{3}$ & 70 & 190 \\
Aqua-regia & $\left(\mathrm{HCl}: \mathrm{HNO}_{3} 3: 1 \mathrm{v} / \mathrm{v}\right)$ & 146 \\
\hline
\end{tabular}

Table 7. Relationship between pressure vessel and sample amount

\begin{tabular}{ccc}
\hline \% Fat content & Sample mass & Closed vessel \\
\hline$<75$ & $<0.5 \mathrm{~g}$ & Low pressure $(2 \mathrm{MPa})$ \\
$<75$ & $>0.5 \mathrm{~g}$ & High pressure $(10 \mathrm{MPa})$ \\
$>75$ & $<0.25 \mathrm{~g}$ & Low pressure $(2 \mathrm{MPa})$ \\
$>75$ & $>0.25 \mathrm{~g}$ & High pressure $(10 \mathrm{MPa})$ \\
\hline
\end{tabular}

time required for decomposition (minutes) and the accuracy of the results, as a consequence of minimal contamination from the environment and from reagents (lesser amounts are required), with no loss of volatile elements. ${ }^{4}$

Microwave assisted flow digestion can be performed in continuous flow systems, stopped flow systems, ambient pressure systems or pressurized systems; several examples have been presented in the literature..$^{18,34-41}$ These systems save time and reagents and have broad applications. By accelerating the reaction through rapid heating, such systems make it feasible to generate reaction products quickly and in larger quantities. ${ }^{38}$ In addition to these favorable characteristics, fume production during wet digestion, contamination and loss of volatile elements can be avoided or minimized when microwave-assisted flow digestion systems are used. Generally a flow system is incorporated into a microwave oven, and the digested sample is collected in flasks, opened for subsequent analysis by some appropriate analytical technique or transported directly to a detector coupled in line with the microwave oven. ${ }^{34}$

\section{Present and Future Trends}

Present and future trends can be summarized by emphasizing the minimal manipulation of samples. In this sense, the analysis of slurries, determinations in situ and on line, and the principle of single flask and automation/ robotics have also been employed for sample decomposition. ${ }^{42-67}$

\subsection{Strategies to perform microwave-assisted decomposition}

As pointed out by Nóbrega et al. ${ }^{43}$ focused-microwave- 
assisted sample preparation is a suitable strategy when dealing with high masses of organic samples. However, the high acid concentration of the digestates may result in difficult routine analytical measurements when using spectroscopic techniques. Acids must be evaporated, but this step may be slow, even when using microwave-assisted heating and requires a scrubber system for acid vapor collection and neutralization.

Two procedures can be used to decrease the acid concentration of digestates. The first is based on acid vapor phase digestion of samples contained in PTFE devices inserted into the microwave flask. The acid solution is heated by absorption of microwave radiation, then the acid vapor partially condenses in the upper part of the reaction flask being partially collected in each sample container. Calcium, iron, magnesium, manganese and zinc were quantitatively recovered in samples of animal and vegetable tissues ${ }^{44}$ using the system presented in Figure 4.

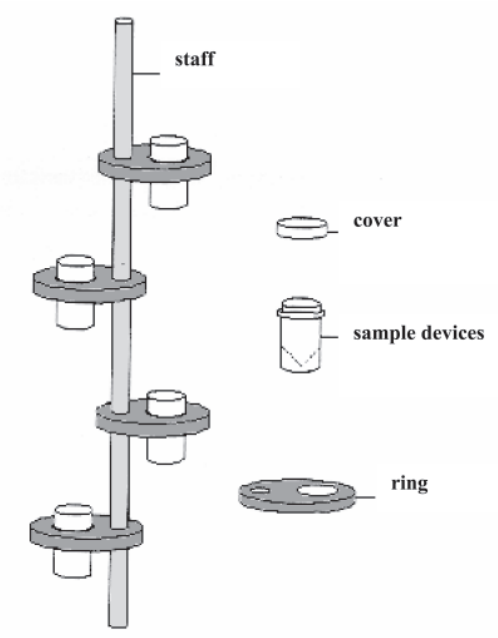

Figure 4. PTFE devices for acid vapor phase microwave-assisted digestion.

The second procedure is based on the gradual addition of liquid samples to a previously heated acid digestion mixture. This procedure was successfully applied for digestion of milk, fruit juices, and red wine. ${ }^{43}$

Based on the first strategy, and using the principle of a single flask ${ }^{45}$ for the entire analytical protocol, Tan et al. ${ }^{46}$ developed a device using 4 flasks ( $4 \mathrm{~mL}$ ) or 5 flasks (2 $\mathrm{mL}$ ), placed inside the glass tube of a focused microwave oven (Figure 5), for pretreatment and determination of some metals in hair samples. Owing to the reduced content in hair samples, $\mathrm{Cu}, \mathrm{Fe}$ and $\mathrm{Zn}(60 \mathrm{mg}$ of sample for each of 4 flasks) were determined by flame atomic absorption and $\mathrm{Mn}$ and Se (30 mg of sample for each of 5 flasks) by electrothermal atomic absorption spectrometry.

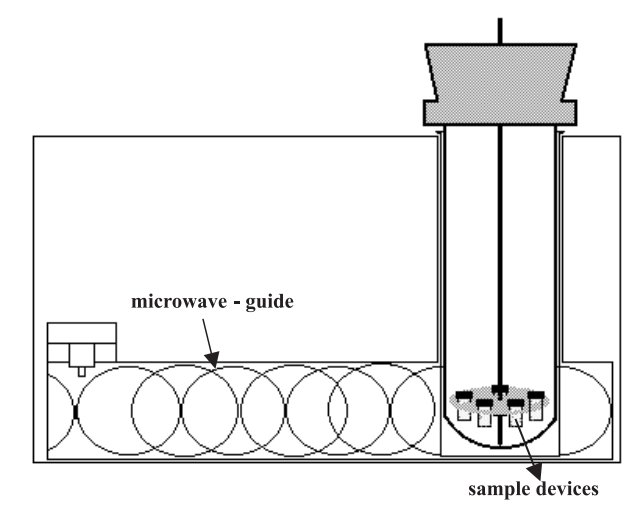

Figure 5. PTFE devices for acid microwave-assisted digestion.

Flores ${ }^{45}$ applied the principle of a single flask to biological samples. The sample (15 $\mathrm{mg}$ of hair or bovine liver) plus $50 \mu \mathrm{L}$ of sulfuric acid and $150 \mu \mathrm{L}$ of nitric acid were placed in $2 \mathrm{~mL}$ mini-polypropylene flasks. The mixture was heated in a conduction oven for $20 \mathrm{~h}$ at $70{ }^{\circ} \mathrm{C}$ or in a conventional microwave oven for $7 \mathrm{~min}$ for As determination in hair samples. After cooling, the volume was made up to $1.5 \mathrm{~mL}$ and the analytes were determined by electrothermal atomic absorption spectrometry.

The main difficulty in such methodologies is caused by the lack of homogeneity of the samples, because only a few mg were used in all examples reported. ${ }^{18,44}$

\subsection{On-line sample decomposition}

On-line sample preparation can be performed using microwave-assisted procedures ${ }^{48-49}$ or by partial chemical decomposition. ${ }^{48}$ On-line partial chemical decomposition using a flow injection system coupled to an ICP-OES was developed for $\mathrm{Cr}, \mathrm{Mn}$ and $\mathrm{Ni}$ determinations in stainless steel. ${ }^{47} \mathrm{An}$ extractor solution consisting of $7.0 \mathrm{~mol} \mathrm{~L}^{-1} \mathrm{HNO}_{3}$ and $6.0 \mathrm{~mol} \mathrm{~L}^{-1} \mathrm{HCl}$, was pumped through a glass reaction chamber $(c a . .5 \mathrm{~cm})$, that contains the samples (as chips) and fiberfill as filters at both extremities, to avoid having particles reach the nebulizer of the spectrometer. Water passed out of the system and was discarded. After commutation, the water flow passed through the reaction chamber, the reaction ceased and the system was cleaned, the reaction chamber plus sample was changed, while the extractor solution was pumped to the spectrometer. Commuting again, a new sample can be analyzed. The analytical frequency was 20 samples per hour.

Focused microwave-assisted on-line sample dissolution, as shown in Figure 6, was applied to orange juice $^{48}$ and wine ${ }^{49}$ samples for determination of nutrients and contaminating elements, applying inductively coupled plasma-optical emission spectrometry. The reactor 
coil was a PTFE tube (4.0 m long and $1.6 \mathrm{~mm}$ i.d.), positioned in the commercial glass tube of the focused microwave oven. A volume of $500 \mu \mathrm{L}$ orange juice sample was mixed at the confluence point with $1000 \mu \mathrm{L}$ of reagent $\left(80 \% \mathrm{v} / \mathrm{v} \mathrm{HNO}_{3}\right.$ ) and transported to the reaction coil by an air carrier. With this on-line digestion system it was possible to analyze 12 samples per hour, minimizing contamination and saving both sample and reagents. ${ }^{48}$

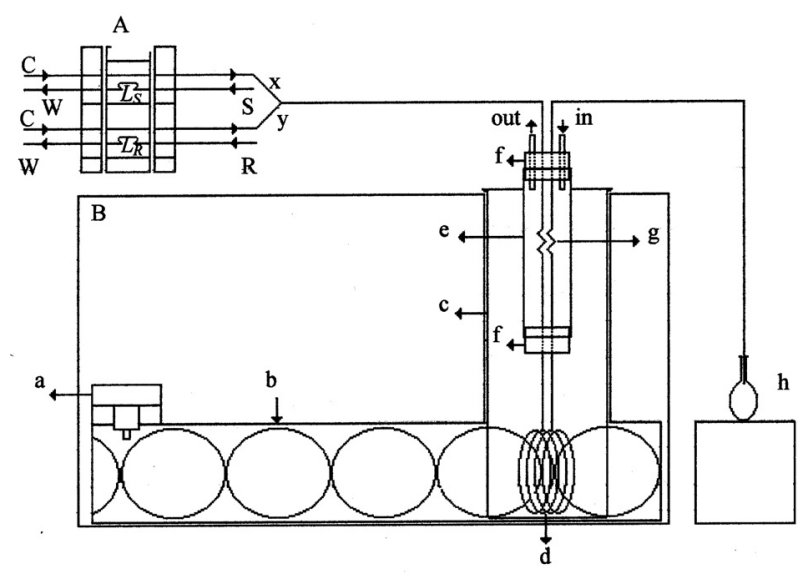

Figure 6. Scheme for line sample dissolution: A Injector diagram: S, sample; R, reagent; $\mathrm{C}$, carrier; $\mathrm{W}$, waste; $\mathrm{L}_{\mathrm{S}}$, sample loop; $\mathrm{L}_{\mathrm{R}}$, reagent loop; B focused microwave: a, magnetron; b, waveguide; c, glass cavity; d, PTFE reactor coil; e, PVC cooler system; f, rubber; g, PTFE coils; h, volumetric flask.

Burgěra and Burgěra ${ }^{40}$ have presented a review on microwave-assisted sample preparation using flow systems. In addition, other publications are available. ${ }^{50,51}$

\subsection{Solid samples and slurry analysis}

In situ sample preparation is also employed to prevent contamination, when only a small amount of sample is available. For blood samples, direct introduction of sample into a graphite furnace, together with the reagent, results in minimization of the matrix effects and allows simultaneous determination of $\mathrm{Mn}$ and $\mathrm{Se}^{52}$ or $\mathrm{Cu}, \mathrm{Fe}$ and $\mathrm{Zn}^{53}$ by simultaneous electrothermal atomic absorption spectrometry.

The direct sample introduction, as a slurry, has been used as a sample pretreatment and presents the advantage of avoiding the use of reagents and dilutions that can introduce contaminants. No losses of volatile elements, safety of operation, and the small amount of sample are attractive characteristics of this method. ${ }^{9,18,44,54-60}$

Direct solid sampling electrothermal atomic absorption spectrometry (SS-ETAAS) is applicable to trace and ultratrace element determination in technological, biological and environmental samples. ${ }^{55,61}$ Reduced sample requi- rements, the possibility of performing the sample decomposition inside the graphite furnace, operational simplicity and high detectability are the main attributes of SS-ETAAS. The sample is directly weighed into a boattype platform using a micro-balance, and the platform is inserted into the furnace using a manual or automatic solid sampler. Thus, there is no sample pretreatment and only heat, in the presence of an appropriate modifier, is used for minimization of the matrix effect.

Slurry and solid sample analyses require the characterization of a number of variables, such as homogeneity, grinding and sieving, addition of stabilizing or wetting agents and particle size. ${ }^{18,26,44,62}$

\subsection{Microwave plus ultraviolet radiation/automation and robotics}

A microwave-assisted high temperature UV digestion for accelerated decomposition of dissolved organic compounds or slurries was developed by Florian and Knapp. ${ }^{63}$ Ultraviolet radiation is generated by an immersed electrodeless $\mathrm{Cd}$ discharge lamp (228 nm), activated by the microwave field in the oven cavity, providing temperatures up to $250-280{ }^{\circ} \mathrm{C}$. This system is ideal for very low trace analyses, due to low blank values and low acid concentrations ( $c a .0 .1 \mathrm{~mL} \mathrm{HNO}_{3}, 5 \mathrm{~mL} \mathrm{H}_{2} \mathrm{O}$ and $1 \mathrm{~mL}$ $\mathrm{H}_{2} \mathrm{O}_{2}$ for digesting $0.1 \mathrm{~g}$ of powdered organic matrices).

Automation and robotics are already used in sample preparation. ${ }^{34,51,63-67}$ A review about mechanization for sample pretreatment has been published by Arruda and Santelli. ${ }^{34}$

Han et al. ${ }^{64}$ presented a microwave system that allows the decomposition of the sample and the evaporation of the digestates for trace element determination in silicabased materials.

Norris et al. ${ }^{65}$ presented a robotic system that is able to weigh the sample, perform the addition of acids, process the digestion in a microwave oven, dilute and transfer the solution to a recipient for analysis, and clean the system. The analytical frequency was around 3 samples per hour.

Torres et al. ${ }^{66}$ described the determination of $\mathrm{Fe}, \mathrm{Cu}$ and $\mathrm{Zn}$ in soil samples using a robotic system.

Kingston et al.$^{67}$ reported on automated analysis, with sub $\mu \mathrm{g} \mathrm{g}^{-1}$ detection limits and the trend toward speciation, rather than just elemental analysis. They described new instrumentation, which integrated sample preparation and analysis, to enable on-line near real-time analyses.

\subsection{Quality assurance}

The operations undertaken in the course of sample 
preparation, plus the sampling and methodology validation steps, must be considered in order to develop quality assurance in the analytical protocol. Only recently has Eurachem published a preliminary document on these issues. ${ }^{68}$ Both traceability and measurement uncertainty in sample pretreatment must be considered in order to represent correctly the original status of analyzed samples.

\section{Conclusions}

This review discusses the similarities between the methods for sample preparation developed in Brazil and abroad and that nowadays, new ideas on this subject follow different directions, from no or minimal sample preparation to total dissolution, fully automated or not. The main aspects to be considered for sample preparation are the amount of the sample, the quantities of the elements in the sample, the need for total or partial digestion, the instrumental methods available for element determination, low reagent consumption, low residue generation, the integrity of the sample and the uncertainty in the measurements.

\section{Acknowledgements}

The author thanks FAPESP and CNPq for financial support, the colleagues and students of the Laboratory of Emission and Absorption Spectrometry (LEEAA) from the Chemistry Institute of the University of São Paulo for helpful discussions and Dr. Liliana Marzorati and Prof. C.H. Collins for English revision.

\section{References}

1. Iyengar, G.V.; Subramanian, K.S.; Woittiez, J.R.W.; Elemental Analysis of Biological Samples. Principles and Practice, CRC Press: Boca Raton, 1997.

2. Bock, R.; A Handbook of Decomposition Methods in Analytical Chemistry, International Text Book Company: London, 1979.

3. Pinta, M.; Modern Methods for Trace Element Analysis, Ann Arbor Science Publ.: Ann Arbor, 1978.

4. Kingston, H.M.; Jassie, L.B.; Introduction to Microwave Sample Preparation- Theory and Practice, ACS Professional Reference Book: Washington D.C., 1988.

5. Jarvis, K.E.; Gray, A.L.; Houk, R.S.; Handbook of Inductively Coupled Plasma Mass Spectrometry, Blackie \& Son: Glasgow, 1992.

6. Krug, F.J.; Métodos de Decomposição de Amostras, III Workshop sobre Preparo de Amostras, FAPESP, São Carlos, 2000.

7. http://sampleprep.duq.edu/sampleprep/, accessed in August 2002.
8. Barnes, R.M.; Short Course on Plasma Spectrochemical Analysis. Inductively Coupled Plasma Analysis, Department of Chemistry, University of Massachusetts: Amherst, 1991.

9. Arruda, M.A.Z.; Gallego, M.; Valcárcel, M.; Anal. Chem. 1993, 65,3331 .

10. Costa, A.C.S.; Dissolução de Amostras Inorgânicas, III Workshop sobre Preparo de Amostra, FAPESP, São Carlos, 2000.

11. McHard, J.A.; Winefordner, J. D.; Attaway, J.A.; J. Agric. Food Chem. 1976, 24, 41.

12. McHard, J.A.; Foulk, S.J.; Nikdel, S.; Ullman, A.H.; Pollard, B.D.; Winefordner, J.D; Anal. Chem. 1979, 51, 1613.

13. Cohen, E.; Sharon, R.; Volman, L.; Hoenig R.; Saguy, I.; J. Food Sci. 1984, 49, 987.

14. Cervera, M.L.; Lopez, J.C.; Montoro, R.; Microchem. J. 1994, 49, 20.

15. Nikdel, S.; Temelli, C.M.; Microchem. J. 1987, 36, 240.

16. Rezaaiyan, R.; Nikdel, S.; J. Food Sci. 1990, 55, 1359.

17. Pregnolatto, W.; Pregnolatto, N.P.; Normas Analíticas do Instituto Adolfo Lutz- Métodos Químicos e Físicos para Análise de Alimentos, $3^{\text {rd }}$ ed., Instituto Adolfo Lutz: São Paulo, 1985.

18. Schwedt, G.; The Essential Guide to Analytical Chemistry, John Wiley and Sons: Chichester, 1997.

19. Skoog, D.A.; West, D.M.; Holler, F.J.; Fundamentals of Analytical Chemistry, $6^{\text {th }}$ ed., Saunders College Publ.: New York, 1992.

20. Kotz, L.; Kaiser, G.; Tschöpel, P.; Tölg, G.; Fresenius Z. Anal. Chem. 1972, 260, 207.

21. Bernas, B.; Anal. Chem., 1968, 40, 1682.

22. Knapp, G.; Fresenius Z. Anal. Chem. 1984, 317, 213.

23. Korn, M.; Uso de Ultra-som para Preparo de Amostras, III Workshop sobre Preparo de Amostras, FAPESP: São Carlos, 2000.

24. Nascentes, C.C.; Souza, C.S.; Korn, M.; Arruda, M.A.Z.; J. Braz. Chem. Soc. 2001, 12, 57.

25. Glimowski, J.; Glimowska, K.; Anal. Chim. Acta 1996, 375, 111.

26. Filgueiras, A.V.; Capello, J.L.; Lavilla, I.; Bendicho, C.; Talanta 2000, 53, 433.

27. Okuma, A.A.; Pinto F.G.; Carazza, F.; Abtsracts of $24^{\underline{a}}$ Reunião Anual da Sociedade Brasileira de Química, Poços de Caldas, 2000.

28. Knapp, G.; Raptis, S.E.; Kaiser, G.; Tölg, G.; Schramel, P.; Schreiber, B.; Frezenius Z. Anal. Chem. 1981, 308, 97.

29. Campos, R.C.; Curtius, A.; Berndt, H.; J. Anal. At. Spectrom. 1990, 5, 669 .

30. Magalhães, C.E.C; Krug, F.J.; Fostier, A.H.; Berndt, H,; J. Anal. At. Spectrom. 1997, 12, 1234.

31. Gouveia, S.T; Nóbrega, J.A.; Fatibelo-Filho, O.; J. Braz. Chem. Soc. 2000, 11, 261.

32. Howard, A. G.; Statham, P. J.; Inorganic Trace Analysis. Philosophy and Practice, John Wiley and Sons: Chichester, 1993. 
33. Cavicchioli, A. M.; Gutz, I.G.R.; J. Braz. Chem. Soc. 2002, $13,449$.

34. Arruda, M.A.Z.; Santelli, R. E.; Quim. Nova 1997, 20, 638.

35. Smith, P.E.; Arsenault, E.A.; Talanta 1996, 48, 1207.

36. Lamble, K.J.; Hill, S.J.; Crit. Rev. Analyst 1998, 123, 103R.

37. http://www.milestonesci.com/, accessed in August 2002.

38. Pereira-Filho, E.R.; Rohwedder, J.J.R.; Arruda, M.A.Z.; Analyst 1998, 123, 1023.

39. Pereira, A.V.; Aniceto, C.; Fatibello-Filho, O.; Analyst 1998 , 123, 1011.

40. Burguera, M.; Burguera, J.L.; Anal. Chim. Acta 1998, 366, 63.

41. Noh, M.F.M.; Hamid, T.A.; Ismail, T.; At. Spectrosc. 1998 , 19, 95.

42. Theodoridis, G.; Papadoyanis, I.N.; Mikrochim. Acta 2001, 136, 1999.

43. Nóbrega, J.A.; Santos, D.M.; Trevizan, LC.; Costa, L.M.; Nogueira, A.R.A., Abstracts of Trends in Sample Preparation, Graz, Áustria, 2002.

44. Araujo, G.C.L.; Nogueira, A.R.A.; Nóbrega, J.A.; Analyst 2000 , 125, 1861.

45. Flores, E.M.; Ph.D Thesis, Universidade Federal do Rio Grande do Sul, Porto Alegre, 1997.

46. Tan, C.S.; Oliveira, E.; Oliveira, P.V.; Abstracts of $11^{\circ}$ Encontro Nacional de Química Analítica, Campinas, SP, 2001.

47. Capri, M.R.; Master Sc. Dissertation, Universidade de São Paulo, São Paulo, 2001.

48. Fili, S.P.; Oliveira, E.; Oliveira, P.V.; Abstracts of Sixth Rio Symposium on Atomic Spectrometry, Concepción-Púcon, Chile, 2000.

49. Spaziani, M.; Oliveira, E.; Oliveira, P.V.; Abstracts of Seventh Rio Symposium on Atomic Spectrometry, Florianópolis, SC, 2002.

50. Oliveira, C.C.; Santini, R.P.; Zagatto, E.A.G.; Anal .Chim. Acta 2000, 413, 41.

51. Neira, J.Y.; Neyes, N.; Nóbrega, J.A.; Lab. Robot. Autom. 2000, 12, 246.

52. Correia, P.R.M.; Oliveira, E.; Oliveira, P.V.; Talanta 2002, 57, 527.
53. Correia, P.R.M.; Oliveira, E.; Oliveira, P.V.; Anal. Chim. Acta 2002, 458, 321.

54. Kurfürst, U.; Solid Sample Analysis- Direct and Slurry Sampling using GF-AAS and ETV-ICP, Springer: Berlin, 1998.

55. Bendicho, C.; de Loss-Vollebregt, T.C.; J. Anal. At. Spectrom. 1991, 6, 353.

56. Miller-Ihli, N.J.; Anal. Chem. 1992, 64, 964.

57. Magalhães, C.E.C; Arruda, M.A.Z.; Quim. Nova 1998, 21, 459.

58. Vale, M.G.R.; Silva, M.M.; Nichele, T.Z., Santos, D.H.; Hardt, D.R.; Abstracts of $10^{\text {th }}$ Encontro Nacional de Química Analítica, Santa Maria, RS, 1999.

59. Silva, J.B.B.; Maia, S.M.; Silva, M.A.M.; Curtius, A.J.; Abstracts of $10^{\text {th }}$ Encontro Nacional de Química Analítica, Santa Maria, RS, 1999.

60. Barbosa Jr., F.; Lima, E.C.; Krug, F.J.; Abstracts of $10^{\circ}$ Encontro Nacional de Química Analítica, Santa Maria, RS, 1999.

61. Silva, C.S.; Nomura, C.S.; Oliveira, E.; Nóbrega, J.A.; Oliveira, P.V.; Abstracts of Trends in Sample Preparation, Graz, Áustria, 2002.

62. Barnes, R.M.; Abstracts of Trends in Sample Preparation, Graz, Áustria, 2002.

63. Florian, D.; Knapp, G.; Anal. Chem. 2001, 73, 1515.

64. Han, Y.; Kingston, H.M.; Richter, R.C.; Pirola, C.; Anal. Chem. 2001, 73, 1106

65. Norris, J.D.; Preston, B.; Ross, C.M.; Analyst 1992, 117, 3.

66. Torres P.; Ballestenos, E.; De Castro, M.D.L.; Anal. Chim. Acta 1995, 308, 371.

67. Kingston, H.M.; Han, Y.; Link, D.; Stewart, L.; Abstracts of Trends in Sample Preparation, Graz, Áustria, 2002.

68. Wegscheider, W.; Walner, U.; Moser, J.; Abstracts of Trends in Sample Preparation, Graz, Áustria, 2002.

Received: October 19, 2002

Published on the web: April 15, 2003

FAPESP helped in meeting the publication costs of this article. 